\title{
Development of Perverse Environmental Subsides for Sheep Production in Iceland
}

\author{
Olafur Arnalds \\ Faculty of Agricultural and Environmental Sciences, Agricultural University of Iceland, Borgarnes, Iceland \\ Email: oa@lbhi.is
}

How to cite this paper: Arnalds, O. (2019) Development of Perverse Environmental Subsides for Sheep Production in Iceland. Agricultural Sciences, 10, 1135-1151. https://doi.org/10.4236/as.2019.109086

Received: August 13, 2019

Accepted: September 6, 2019

Published: September 9, 2019

Copyright (C) 2019 by author(s) and Scientific Research Publishing Inc. This work is licensed under the Creative Commons Attribution International License (CC BY 4.0).

http://creativecommons.org/licenses/by/4.0/

\begin{abstract}
Sheep production in Iceland is heavily subsidized with a part of the payments tied to land condition and compliance with sustainable land use according to a Quality Management System (QMS). A large proportion of the rangelands used for sheep grazing are public lands. The paper is based on Land Improvement Plans (LIP's) and Soil Conservation of Iceland (SCSI) correspondence obtained by appeal under the Information Act. The results show that "green payments" are made for use of land that fails to meet the criteria given for such payments, based on the extent of barren areas, active soil erosion, and vegetation condition. Strong formal objections by the SCSI about the content and implementation of QMS have been ignored. It is further shown that the land use section of the QMS (L-QMS) is non-transparent and not well scientifically grounded. The use of the term "sustainable land use" is confounded when used to justify the use of collapsed ecosystems. The LIP's show high to extreme grazing intensities on land in poor condition, thus further defying ideas for green subsidy schemes. The investigation reveals serious conflicts between environmental and agricultural sectors, at agency and ministerial levels, which is enhanced by incoherent legislation structures. It is vital to reconstruct the green subsidies for sheep farming in Iceland, based on science and best available information with a much broader stakeholder participation than at present, involving multi-sectoral agencies and scientists, NGO's, communities, the general public, and land users.
\end{abstract}

\section{Keywords}

Agricultural Subsidies, Agro-Environmental, SLM, Land Condition, Sheep Grazing

\section{Introduction}

Iceland is a $103,000 \mathrm{~km}^{2}$ island in the North Atlantic Ocean, with about 350,000 
inhabitants.

Icelandic agriculture is primarily based on dairy production and sheep farming, while poultry and vegetable production is also of importance. Farms in operation are about 2600 with about 80,000 cattle and 430,000 sheep (http://www.statice.is/). Horses, some 70,000, are mainly kept for recreational use. Cattle and sheep are held indoors during winter, which calls for haymaking and storing fodder for the winter [1]. Cultivated land is $1300 \mathrm{~km}^{2}$ consisting mostly of permanent hay fields, which are plowed every 5 - 10 years [2]. Sheep farming constitutes about $13 \%$ of the agricultural output including subsidies, but this percentage is considerably lower if subsidies are excluded (http://www.statice.is/). Both sheep and dairy production are subsidized by the government, with the subsidies rating among the highest in the world [2]. Sheep meat production costs exceed the farmers' meat revenues on average. Sheep subsidies amounted to about 5.2 billion Icelandic kr. in 2019, some 136 million $€$ and are the source majority of the income of sheep farms. Most sheep farmers amend their income by employment off the farm.

Most of the sheep are set free on open rangelands in summer, frequently on communal grazing areas, generally from late June or early July to early September when the sheep are gathered. The rangelands include much of the highlands of Iceland ( $>400 \mathrm{~m}$ above sea level). Most of these areas are public lands ("Pjóðlendur" in Icelandic), under the joint jurisdiction of the Prime Minister's Office and the relevant community, with the farmers holding grazing rights to the communal grazing areas. The sheep are left unattended, as there is no predation pressure in the rangelands apart from occasional killings by the Arctic fox when the lambs are young.

A large proportion of the highland communal areas used for grazing have limited vegetation cover and have been subjected to severe ecosystem collapse since the arrival of man to Iceland around 870 [3]. The remaining vegetation is often in poor condition (Figure 1). The commons with the least vegetation cover

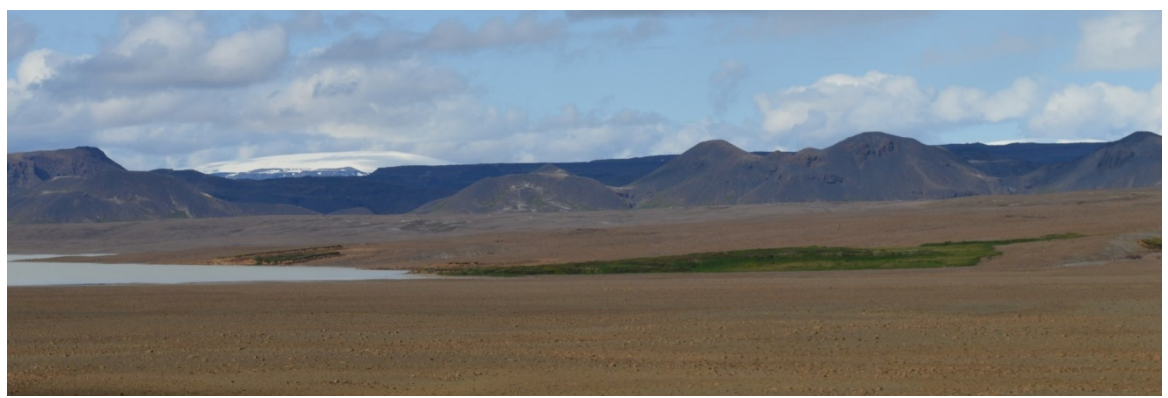

Figure 1. Example of degraded communal areas in Iceland. Vegetation remnants in a barren "desert" area at $2-300 \mathrm{~m}$ elevation. A $1-2 \mathrm{~m}$ thick fertile Andosol has been fully removed by erosion by wind and water, leaving the barren gravelly surface behind. The lower elevations of this area were fully covered with birch woodlands and harvested for fuel-wood into the 1600's. The degradation was land-use driven. The area is a common and continues to be grazed by sheep. Birch woodlands can be returned to areas like these by strategic restoration efforts [9] Photo: O. Arnalds 2018. 
and with the most severe erosion problems have been deemed unsuitable for grazing after an extensive survey by the Agricultural Research Institute and the Icelandic Soil Conservation Service (SCSI) [4]. Although sheep grazing in the highlands has been subject to controversy, attempts to exclude grazing from some of the poorest grazing lands have failed (see [5] [6]). Icelandic nature conservation NGO's and the OECD [7] have been very critical of land use policies in Iceland, and especially the poor state of the highlands. Grazing of the poorly vegetated commons constitutes a minor part of the total sheep grazing in Iceland [5] and therefore only a small proportion of the total agriculture. Hence, the use of the highland rangelands is often more based on traditions than economic or sustainable land use motivations [8].

After series of meetings and consultation between primary actors in 1998-2000 a common understanding was reached to tie part of the sheep subsidies to responsible land use. Subsequent development lead to new legislation in 2003 where parts of the subsidies to sheep farmers were linked to standards given by a Quality Management System (QMS), founded on amendments of an existing Farm Commodity Act ("Búvörulög" no 99/1993). The QMS regulatory framework included a section on land use (L-QMS in this paper). The Icelandic L-QMS system is a subsidy payment system that is linked to criteria for quality and condition of the grazing areas and guidelines for grazing intensities; criteria which need to be met by the farm operation in order to be entitled to receive the subsidies.

In recent years it has come to the attention of ecologists and soil scientists that no communal gazing areas have been protected from grazing based on the implementation of the L-QMS agreement.

Several attempts were made to obtain information about the implementation of the L-QMS, but these were denied by the Icelandic Food and Veterinary Authority (IFVA) who is responsible for subsidy payments according to standards set out by the Farm Commodity Act (99/1993) and the QMS regulations. Therefore, it was impossible to evaluate how the system was working or if it met initial expectations. After having a formal request for information on the L-QMS denied by the IFVA, the author of this paper appealed the decision under the Icelandic Information Act Regarding Environmental Issues (no 23/2006), and The Information Act (no 140/2012), to the "Information Ruling Committee", which ruled that the IFVA should release information pertaining the implementation of the L-QMS (ruling 747/2018) [10]. Subsequently, the IFVA released to the author 38 Land Improvement Plans (LIP's) for larger rangeland areas (up to 2700 $\mathrm{km}^{2}$ ), most used by several users, and eight LIP's for smaller grazing areas, most often used by single users.

The Soil Conservation Service of Iceland (SCSI) was an instrumental agency regarding the formulation of standards and in the implementation of the L-QMS. After the ruling mentioned above (747/2018, UU, 2018), the author requested all official correspondence regarding the L-QMS from the SCSI. Acknowledging the 
precedence set by the ruling, the SCSI handed out 91 documents related to the L-QMS implementation.

The following paper presents a critical review of: 1) how the land use part of the L-QMS has been carried out since it was instigated; 2) the development and implementation of land use requirements; 3 ) information and standards for land use set forth by the LIP's; 4) how professional understanding of the leading national agency on land use management (SCSI) was handled during the implementation; and 5) how successful the L-QMS has been overall in conserving the health of the highland rangelands in Iceland.

\section{The Framework for the Quality Management System (QMS)}

\subsection{Laws and Regulations}

Overview of the legal framework referred to in this paper is presented in Table 1. The table also lists a "Declaration of Intent", an important document in the

Table 1. Overview of laws and regulations relevant to the land use part of the quality management system of sheep production (L-QMS), with short comment on each. The list includes a declaration from 2000.

\begin{tabular}{|c|c|c|c|}
\hline Type & No/Yr & Title & Comments \\
\hline Law & $155 / 2018$ & $\begin{array}{l}\text { On Soil and Land } \\
\text { Conservation }\end{array}$ & $\begin{array}{l}\text { Modernization of } 1965 \text { law. Important } \\
\text { provisions still under 6/1986 (Ministry for } \\
\text { Industries and Innovation). }\end{array}$ \\
\hline Law & $6 / 1986$ & Act on Rangelands & $\begin{array}{l}\text { Foundation from } 1969 . \text { Under Ministry for } \\
\text { Industries and Innovation; ensures } \\
\text { influence of the agricultural sector } \\
\text { on land use issues. }\end{array}$ \\
\hline Law & $99 / 1993$ & $\begin{array}{c}\text { Farm } \\
\text { Commodity Act }\end{array}$ & $\begin{array}{l}\text { Legal basis for the QMS. Amendments } \\
\text { made later to accommodate changes of } \\
\text { regulations. }\end{array}$ \\
\hline Statement & 2000 & $\begin{array}{l}\text { Declaration of Intent } \\
\text { (“Viljayfirlýsing”) }\end{array}$ & $\begin{array}{l}\text { Declaration signed by user's associations, } \\
\text { national agencies and the government. }\end{array}$ \\
\hline Regulation & $175 / 2003$ & $\begin{array}{l}\text { Quality Management } \\
\text { in Seep Farming } \\
\text { (QMS) }\end{array}$ & $\begin{array}{l}\text { Initial foundation for the QMS, some basic } \\
\text { criteria on the land use part (L-QMS). }\end{array}$ \\
\hline Regulation & $10 / 2008$ & QMS-Update & $\begin{array}{l}\text { Major changes on assessment and } \\
\text { classification of land condition of } \\
\text { the L-QMS. }\end{array}$ \\
\hline Regulation & $1160 / 2013$ & QMS-Update & $\begin{array}{l}\text { Controversial changes relaxing demands } \\
\text { for environmentally acceptable land use. }\end{array}$ \\
\hline Regulation & $536 / 2015$ & QMS-Update & $\begin{array}{l}\text { Relaxing rules. Role of SCSI minimized, } \\
\text { implementation left entirely to the } \\
\text { agricultural sector. }\end{array}$ \\
\hline Regulations & $\begin{array}{c}1166 / 2017 \\
511 / 2018\end{array}$ & QMS-Updates & No significant changes to L-QMS. \\
\hline
\end{tabular}


development of the QMS framework. A more comprehensive coverage of laws and regulations pertaining agriculture and soil conservation, including history of their development, was provided by Fannarsson et al. on the laws [11], Stefánsson on the QMS [12], and Aradottir et al. on land use and restoration issues [9].

The main incentives for implementation of the QMS for sheep production was to ensure the quality of the products, enhance good farm- and book-keeping practices for the production, and to ensure good land use practices (Farm Commodity Act, 99/1993). The growing national concern for the state of the Icelandic rangelands, especially following the National Soil Erosion Mapping project, led to discussions between major stakeholders that culminated in a "Declaration of Intent" in the year 2000. The actors involved in the declaration included the Farmers Association of Iceland, the Sheep Farmers Association, the Agricultural Ministry (now Ministry for Industries and Innovation), the SCSI, and the Agricultural Research Institute. A framework was laid out for guidelines regarding the implementation of the declaration [13]. The L-QMS was initiated in 2003 with a new regulation (175/2003), however it was not implemented until later. While taking notice of the "Declaration of Intent" from 2000, the L-QMS, is based on the "Farm Commodity Act" (99/1993) which was amended to allow for its implementation. The regulatory framework for the L-QMS has since been changed several times, hence the QMS history shown in Table 1.

\subsection{Land Use Criteria}

The condition criteria under the first L-QMS regulation (2003) was based on: 1) soil erosion categories as per the national soil erosion assessment methods [4] and 2) vegetation condition as indicated by simple vegetation classes (types), which were described by Arnalds and Barkarson [5]. The information on soil erosion and vegetation condition was coined into five overall condition classes: A. Very good-good; B. Fair; C. Poor; D. Bad; E. Very bad. The vegetation classes were established and mapped for the whole country under the Agricultural University of Iceland Farmland Database project [14]. According to this system, commons with more than $15 \%$ of land in very bad condition (class E) were considered unsuitable for grazing, thus requiring LIP and/or exclusion from grazing. Likewise, areas could not have more than $66 \%$ land in classes D $+\mathrm{E}$ or be more than $75 \%$ barren. Arguably, the system was quite lenient, e.g., the threshold value of $75 \%$ for barren is extremely high. The present author's perception is that this was an attempt to make adjustment to the system easier for farmers. It is noteworthy that for land in the poorest condition it was explicitly stated that some LPI areas may need to be excluded from grazing at the end of the 10-year LIP period.

Considerable changes were made to this scheme in 2013 (regulation 1160/2013). The land assessment was now based on a SCSI booklet by Jonsdottir [15]. Land condition was described by six categories, based on visual indicators. 
The system used condition classes 0 - 5 as follows: 0. Excellent; 1. Good; 2. Somewhat poor; 3. Poor; 4. Very poor; 5 . Not suitable for grazing. This is still the basis for the L-QMS. Class 3 can include poor heathlands and barren land, while barren land becomes prominent in category 4 . Class 5 consists chiefly of deserts or areas where erosion is destroying the remnants of vegetated ecosystems. The extent of land in these condition classes was used to construct an overall scheme for both homelands and communal grazing lands, the latter presented in Table 2.

This represents a substantially simplified system from previous regulations. Only two recommendations are made, LIP's are required or not required, and the protection requirement from 2003 has been removed, a point discussed later in the paper. Table 2 is used as a reference for the discussion of the LIP's.

It can be argued that the term "not suitable for grazing" used only for condition class 5 should apply to 4 and in part for condition class 3 as well, especially all barren areas and areas where pronounced soil erosion is taking place. It may also be argued that areas with full vegetation cover, nonetheless in severely degraded state, should be placed in an inferior condition class. This system, like its predecessor from 2003, is arguably too lenient and it does not take into account increased knowledge about the ecology of these systems.

\subsection{Summary of Existing Land Improvement Plans (LIP's)}

The key ingredients of the LIP's include 1) exclusion from grazing on parts of the commons in the poorest condition by slaughtering all sheep found grazing there during the fall gathering; 2) land reclamation by grass seed and fertilizers (average $<1 \%$ of the commons); 3 ) shortening of the summer grazing period; and 4) reduction in the overall number of sheep according to guidelines given by the SCSI and no horse grazing. Each LIP is issued for 8 - 10 years.

A summary compiled from the LIP's is provided in Table 3. It summarizes information for 36 of the 38 commons, as information from two of them was deemed insufficient. The data represent a collective area of $>20,000 \mathrm{~km}^{2}$ or about $20 \%$ of Iceland. Parts of the commons are declared non-grazed for various reasons; hence the total size of the grazed areas is $15,600 \mathrm{~km}^{2}$ according to the LIP's. The total number of ewes in the dataset is 62,240. Using 1.7 lamb per ewe, on average, brings the number of animals grazing these commons during summer to some 106,000 heads.

The threshold for the $3+4+5$ criterion (Table 3 ) are exceeded by far $(>50 \%)$

Table 2. Criteria for evaluating land under the L-QMS according to the 2013 scheme (regulation 1160/2013 in Table 1 (see [15])). Class 5 is the poorest in terms of land condition, see text. Classes 3, 4 and 5 are combined in the last column of the table.

\begin{tabular}{ccc}
\hline & Class 5 & Classes 3+4 +5 \\
\hline LIP not required & $<5 \%$ & $<33 \%$ \\
LIP required & $>5 \%$ & $>33 \%$ \\
\hline
\end{tabular}


Table 3. Summary information from 36 communal and private grazing areas where Land Improvement Plans (LIP's) were required. First line indicates data for commons that do not meet the regulation criterion, i.e. with $>33 \%$ of the land in condition classes $3+4+5$. Second line shows data for commons where this criterion is grossly exceeded $(>50 \%$ of the land in $3+4+5$ ). Third line shows data for commons not meeting criterion by having $<5 \%$ of land in condition class 5 . Forth line shows where this criterion is grossly exceeded ( $>10 \%$ of the land in condition class 5 ). Latter part of the table shows data for commons where grazing intensities are high; $<8$ (high), $<5$ (very high) and $<2$ (extreme) as ha/ewe per land in condition classes $0+1+2$. Number of ewes in these commons and their total areal are also shown.

\begin{tabular}{ccccc}
\hline Condition criteria & $\begin{array}{c}\text { No of } \\
\text { commons }\end{array}$ & $\begin{array}{c}\text { \% of } \\
\text { commons }\end{array}$ & $\begin{array}{c}\text { No of } \\
\text { ewes }\end{array}$ & $\mathbf{k m}^{2}$ \\
\hline$>33 \%$ in $3+4+5 ;<67 \% 0+1+2$ & 35 & 97.2 & 60,090 & 20,348 \\
$>50 \%$ in $3+4+5 ;<500+1+2$ & 23 & 62.1 & 42,570 & 14,188 \\
$>5 \%$ in 5 & 8 & 22.2 & 15,150 & 7563 \\
$>10 \%$ in 5 & 4 & 11.1 & 89,050 & 3839 \\
\hline Grazing intensity & & & & \\
$<8$ ha/ewe; high & 23 & 63.9 & 38,770 & 8423 \\
$<5$ ha/ewe; very high & 15 & 41.7 & 25,670 & 5412 \\
$<2$ ha/ewe; extreme & 8 & 22.2 & 7770 & 1712 \\
\hline
\end{tabular}

in 23 , or $62 \%$ of the commons and four exceed the condition class 5 criterion by far $(>10 \%)$ indicating the severe condition of these areas. Values for good land $(0$ $+1+2)$ are correspondingly lower. Most of the commons requiring LIP's are within the volcanic zones of South- and Northeast Iceland, which coincides with the most vulnerable ecosystems in the country [3]. Most of the sLIP's include crude maps showing the division into the 0 - 5 land condition classes described above. This cannot be considered instructive information about the resource. More detailed data for soil erosion, vegetation types and cover, ecotypes, soils, types of barren surfaces, elevation (major factor on productivity and susceptibility of vegetation systems) would be desirable. Such knowledge can aid in reaching meaningful discussions among stakeholders and aid in developing adaptive management systems.

The LIP's reveal surprising grazing intensities in many of the commons (here discussed in ha of grazing land for each ewe; ha/ewe). The first L-QMS regulation (175/2003) introduced a concept of "forage-abundance", and suggested that eight ha of the most common grazing land (poor heathlands and vegetation at higher elevations) were needed per ewe. This concept was omitted in subsequent regulations (2008 and later) and the SCSI introduced a guideline of 3.3 ha per ewe ( 0.3 ewe per ha). This is a much too high grazing intensity for the marginal grazing lands in Iceland, and likely an error considering the discussion leading up to the forage abundance concept [13]. The lower part of Table 3 presents data for areas with higher grazing intensities than the 8 ha/ewe suggestion from 2003 , considering only land in condition classes $0+1+2$ (good condition). The 
table also presents data for areas with very high grazing intensities ( $<5 \mathrm{ha} / \mathrm{ewe}$ ) and areas with extreme grazing intensities ( $<2 \mathrm{ha} /$ ewe). The grazing intensity in 15 of the 34 commons is very high and in eighth of them extremely high. The grazing intensity in 23 commons (64\%) out of 36 is higher than 8 ha/ewe. This clearly indicates that most of the commons requiring LIP's cannot be considered lightly grazed, contradicting claims of green subsidy compliance for these commons.

At the onset of the L-QMS the aim of the LIP's was to meet criteria for sustainable land use within 8 - 10 yrs. Otherwise the land would need to be protected from grazing. However, the protection provision was removed in subsequent regulations, which has caused a major disagreement between the agricultural sector (ministry and framers' associations) and the SCSI as discussed in Section 3. Currently, all LIP's are approved, even when it is clear that the grazing is not sustainable and that the land will not recover to acceptable levels within reasonable timeframes, especially if grazing is continued. The heavy grazing intensities discussed above emphasize the lack of necessary linkages between land condition and decision making in the regulatory system for green subsidies.

\section{Objections to the Regulatory Framework by the SCSI}

This paper discusses the failure to develop green subsidy system for sheep grazing in Iceland. It is important to study how such failures develop for future efforts to be successful. As stated in the introduction, the author of this paper requested all official correspondence from the Soil Conservation Service of Iceland (SCSI) based on the ruling of the "Information Ruling Committee". The SCSI is the national agency responsible for the welfare of the land, ensuring sustainable land use and for restoring degraded areas (law no 155/2018). The request yielded copies of 91 documents, including both letters and e-mails.

The guidelines and criteria for the L-QMS set by the 2003 regulation did not change much until 2013. The SCSI was increasingly uneasy with the performance of the system. In a letter to the Seep Farmers Association dated November $1^{\text {st }}$, 2012, the SCSI firmly states that, despite the implemented LIP's, it is wrong to conclude that all sheep grazing in Iceland complies with sustainable land management practices. The agency iterated that grazing on land in poor condition, including eroded and barren areas, should be halted and that this should be a major goal of the L-QMS. Later, in a letter to the Sheep Farmers Association dated February $1^{\text {st }}$, 2013, the SCSI declined to support drafts for the next L-QMS regulation (which became 1160/2013).

The debate continued and on April $30^{\text {th }}, 2013$, the SCSI wrote a letter to the Ministry for the Environment and Natural Resources. In the letter, the SCSI states that the criteria for acceptable land use, set forth in the L-QMS regulation $10 / 2008$, deviated profoundly from what had been argued by professionals in ecosystem conservation. Hence, the proposed regulation needed a thorough overhaul with much more stringent rules regarding what could be considered 
suitable grazing land. The letter can both be considered a serious complaint about the implementation of the L-QMS and a request for intervention by the Ministry for the Environment. No response was given to this letter (Sveinn Runólfsson, former director of the SCSI, e-mail to the author, January $19^{\text {th }}$, 2019).

Regulation set in 2013 (1160/2013) became a focus of a major friction between the SCSI on one hand and the Ministry for Industries and Innovation, the IFVA and the Sheep Farmers Association on the other. The SCSI refused to acknowledge that land use within eroded and barren areas met criteria for sustainable land use, especially if the land condition would not foreseeably advance to that level within the 10-year period of the particular LIP. The Sheep Farmers Association protested this in a letter to the SCSI (March 25 $\left.{ }^{\text {th }}, 2014\right)$ stating that the new regulation (1160/2013) could not be changed drastically, in part because new understanding could not be imposed on farmers without previous negotiations. The Association also noted that for many commons it would be impossible to reach more stringent criteria, even with unlimited resources. This is a clear evidence that the intention of the Sheep Farmers Association was to make sure that all grazing met the L-QMS criteria, even the commons in the poorest condition-given that some actions were taken under the LIP's-and thereby for all sheep farmers to receive green subsidies from the state. The Ministry for Industries and Innovation confirmed this understanding of the Sheep Farmers Association in a letter dated March $31^{\text {th }}, 2014$.

In communications leading up to the next L-QMS regulation (535/2015), the SCSI, in letters to the Ministry for Industries and Innovation dated March $30^{\text {th }}$ and April $30^{\text {th }}, 2015$, iterated its position that land in poor condition could not be approved as meeting sustainable land use criteria. However, the Ministry decided to delete Article 13 of the former regulation where it was stated that " $a$ producer that does not fulfill requirements for landuse stated in Chapter IV does not fulfill the requirements of the Quality Management System" and inserted instead: "It is permissible to accept Land Improvement Plan even if it is clear that it does not fulfill requirements for land condition outlined in Appendix I within the timeframe of the Plan". The intention of the Ministry and the agricultural sector is made quite clear by this deletion, all the production shall be certified "green". The response from the SCSI was strong in a letter to the ministry (March 30 $\left.{ }^{\text {th }}, 2015\right)$ :

"The Soil Conservation Service of Iceland is completely against this suggested change. It has long been known that land use (i.e. grazing, author insert) on the commons that are in the poorest state cannot be sustainable until after a long time. An acceptance by the Food and Veterinary Authority of Land Use Plans for the poorest commons and prolonging the Plans again and again would defy all professional foundations and definitions for sustainable land management. It is utterly preposterous (Icelandic: 'fráleitt') to try to convince consumers, let alone scientists and others familiar with the concepts of sustainable development 
and sustainable land management, that land use (i.e. grazing, author insert) on the commons in the poorest condition is sustainable".

Despite the harsh criticism by the SCSI, this controversial change was included in the new regulation (536/2015). Further, the role of the SCSI in the L-QMS was reduced from overseeing the compliance of internationally accepted land use standards to the role of acknowledging standards and definitions of sustainability set by the agricultural sector itself. Apparently, no land use specialists were associated with either the Ministry for Industries and Innovation or the IFVA when these decisions were made. Former longtime director of the SCSI wrote an opinion to the Parliament, dated May $27^{\text {th }}, 2016$, in relation to proposed amendments of the Farm Commodity Act stating inter alia:

"It is clear, no matter what the outcome will be, that the sheep farmers leadership have deceived consumers over recent years stating that sheep production in Iceland is carried out by sustainable land use methods".

The correspondence outlined above is quite remarkable. It sheds a light on how and when a national green subsidy scheme development fails. It reveals how the national agency responsible for the health of land ecosystems in Iceland has been utterly ignored by the decision makers when it comes to establishing standards for sustainable use (grazing) of the Icelandic commons.

\section{4. "Sustainable Land Use"}

The legal and regulatory framework of the L-QMS system makes extensive use of the concept "sustainable land use". The current definition is based on a FAO definition (FESLM) [16]; at the urging of the SCSI. The L-QMS definition reads: "Sustainable land use: land use that does not deplete land resources, such as soils, vegetation and water and ensures at the same time continued function and activity of the system in the future". However, the implementation of the Icelandic L-QMS version leaves out fundamental principles that are related to the concept of sustainable land use. The concepts of sustainable development or sustainable land use are broad and should be regarded more as a framework rather than a well-defined scientific term [16]. The use of the terms should consider the wider context of the term sustainable land management, which includes: 1) productivity, 2) security, 3) protection, 4) viability, and 5) acceptability [16]. The objectives set forth by FAO [16] have been widely used, such as for formulating indicators for sustainable land management in Asia [17].

How do these objectives/pillars of sustainable land use relate to the use of collapsed and barren ecosystems in Iceland? The poor condition of the land needs to be considered in the light of state-and-transition models, where the present condition is not likely to change under stable environmental conditions (see state-and-transition models for Iceland [18]). This may mean that no further deterioration of the systems occurs or that the condition may improve during favorable climatic periods in spite of grazing. However, if the systems do not cross the thresholds to higher states, short improvement periods are often fol- 
lowed by subsequent deterioration during cold spells, volcanic ash-fall and/or increased grazing. Thus, justifying the use of such lands based on the observation that they are "not deteriorating" or even improving in the short term is questionable based on ecological principles. Furthermore, grazing is likely to hinder and even halt altogether the succession of severely degraded lands into improved ecological states.

The economy of grazing of collapsed ecosystems is worth considering at several levels. The production costs are considerably higher than revenues from the production is far from economically viable. The most questionable grazing practices in Iceland (where the LIP's are now in effect) involve a small proportion of the sheep production and cannot be considered important for Icelandic economy or the national agricultural production. In addition, the heavy government subsidies are a prerequisite for continued production for many sheep farmers. The sheep production is subjected to $15 \%$ - $40 \%$ annual surplus, lacking markets for all the produce. The proportion of the sheep production discussed in this paper is not important for food security in Iceland but may, on the other hand, be important for some local communities in terms of employment.

The open range grazing methods are often at odds with other land use emphasis such as afforestation, forestry, urban development, outdoor activities, and tourism. It requires considerable expenditures by communities and the public on fences to protect land from grazing; sheep owners are often not required to keep their sheep within enclosures. Furthermore, the grazing practices often negatively affect ecological restoration by individuals, NGO's, communities and government agencies. Restoration is important to reclaim the productivity of the land, to prevent negative effects of volcanic eruptions (ash-fall) and it can play a major role in climate change mitigation due to high carbon sequestration potential of such actions in Iceland [9] [19]. Climate change has been noted as an important factor on global level in relation to sustainable land management [20]. Grazing that maintains low carbon stocks in soils and vegetation and prevents sequestration cannot be considered as meeting the acceptability objective for sustainable land management. This use of the land has also been deemed unacceptable by the leading Icelandic nature conservation NGO's

(https://landvernd.is/sidur/aherslur-um-natturuvernd-komi-i-buvorusamninga; in Icelandic). They stress that unstainable grazing practices should be halted and that heavily eroded commons should be protected from grazing.

In conclusion: the arguments provided above show that sheep grazing on land in poor condition in Iceland is at odds with the productivity and protection objectives for sustainable land management [16]. It fails to meet objectives for both food and economic security. It furthermore fails to safeguard soil and water resources and has adverse effects on biodiversity. Grazing of barren areas with active erosion and highly degraded vegetation cover is neither viable nor acceptable. The general public, which owns much of the grazing commons, has not been consulted regarding land use practices on these lands. Furthermore, the devel- 
opment of the system has ignored professional opinions offered by the SCSI, the national agency responsible for land use issues. Thus, none of the objectives/pillars for sustainable land use management stated by FAO/Smyth and Dumanski [16] are met by the Icelandic L-QMS.

\section{Discussion}

The condition of the land used for grazing in Iceland is variable, as clearly demonstrated by the National Survey of Soil Erosion [4]. Although large proportions of Icelandic grazing areas have continuous vegetation cover and relatively little soil erosion, some of them are in poor condition and of deprived nutrition status due to millennia of sheep grazing (see [3] [18]). However, this paper deals primarily with areas that have limited vegetation cover and active soil erosion. The underlying motives for implementation QMS, in addition to market certified healthy produce and to increase professionalism in sheep farming, were to ensure and even increase subsidies to the farmers [12]. Preferably, the system should impose minor changes in the production process, including land use [12]. This understanding may well explain the resulting development of the L-QMS described in the previous sections. However, growing concern for land use issues, especially after publication of the National Survey of Soil Erosion in 1997, also became a part of the QMS incentives [5] [11] [12]. It can be concluded that the L-QMS focuses primarily on meat production rather than the condition of the resource. Resource based management plans with stakeholder participation have been shown to yield better results than land-use based focus, exemplified by management of some Bureau of Land Management arid lands in Southwest USA [21].

This paper is chiefly concerned with problems associated with the implementation of the L-QMS, yet the beneficial effects of the scheme should be acknowledged. These include better monitoring of land under the system, partial protection from grazing of land in poor condition and shortening of the grazing period. Also, the L-QMS has prevented horse grazing on some commons. This is important as horse grazing can be very detrimental to subarctic ecosystems due to both trampling and forage removal. It has also been pointed out that the system can potentially create better awareness of land condition [22].

The rejection of professional advice of the SCSI, the agency responsible for land use and conservation in Iceland, constitutes one of the major findings of this research. It highlights weaknesses resulting from decoupling environmental policy making and legislation from the implementation at the government level, allowing other sectors (here the Ministry of Industries and Innovation) to create its own sets of rules and regulations on environmental issues which are not compatible with standards set by the Ministry for the Environment and Natural Resources (Figure 2).

The lack of transparency of the L-QMS system has many negative effects. Correspondence with the IFVA shows that all grazing in Iceland supposedly 


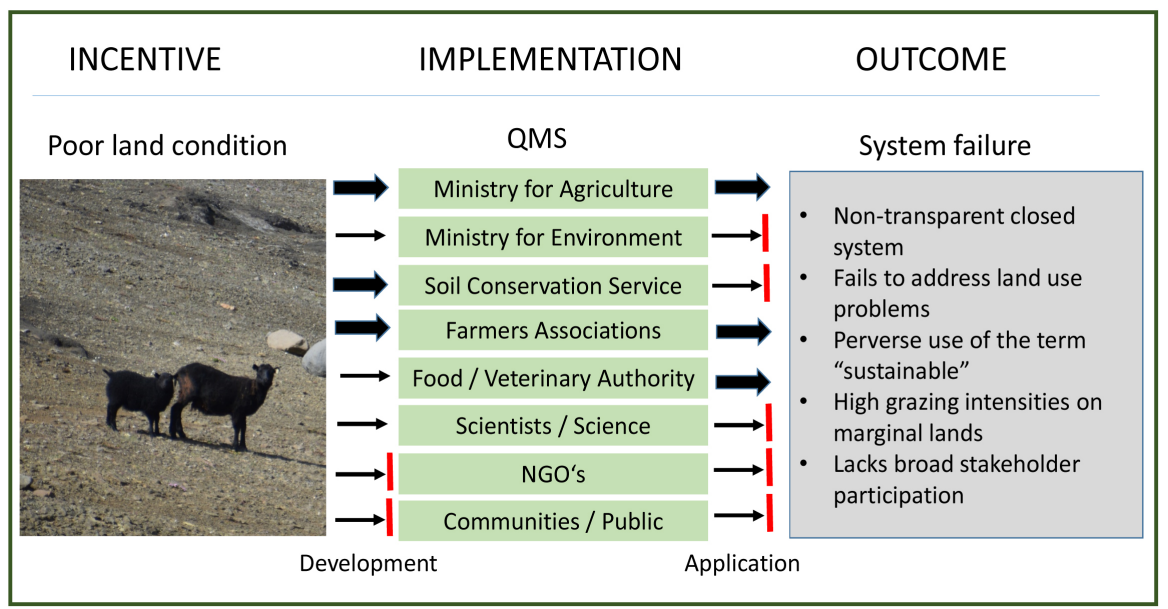

Figure 2. A schematic representation for the incentive, implementation, and outcome of the L-QMS. Broad arrows indicate major contribution, narrower arrow some contribution or consultation. Red vertical bands show unsuccessful involvement or outcomes. Titles of ministries are shortened for clarity. Ministry for Agriculture is now Ministry of Industries and Innovation. Ministry for the Environment is now Ministry for the Environment and Natural Resources. Farmers Associations refers to both the Farmers Association of Iceland and the Sheep Farmers Association.

meets criteria for green subsidies (L-QMS). LIP's were only requested for a small portion of sheep grazing, indicating that the remainder of the grazing was on land in sufficiently good condition judged by the IFVA. The criteria are stated in Table 2, but data are not publicly available for commons that ostensibly do not need LIP's. Known examples (e.g., from [4]) of grazing areas in questionable condition without having to implement LIP's undermine the credibility of the system (example in Figure 1). However, credibility is important in order to maintain the consumer's faith in the product and to build trust between land users and other stakeholders concerned with nature conservation and land use issues in Iceland. Non-transparent land use management systems have been shown to have negative effect on innovation and development in Iceland [22] and elsewhere in Europe [23]. This has also been found true for subsidized farm-based land reclamation projects in Iceland where Petursdottir [18] stressed the need for systematic evaluation of program performance, with regular revision of implementation cycles. They noted that the financial incentives had not facilitated behavioral changes among the farmers, a notion that can also be applied to the L-QMS program based on the findings presented here as well as those of Thorlaksdottir [22].

The review of the existing LIP's indicates that there is a lack of interlink age with science and research in the implementation of the plans and that this is likely to be at the core of the problems with the L-QMS programs (Figure 2). The implementation of LIP's calls for broad approaches and participation (see [24] [25]), using best scientific knowledge and practices. It is necessary to build a consensus within the society for changes that are in agreement with sustainable land use 
[21] [22] [25] [26]. Science-based information has widely been shown to improve the results of grazing schemes on marginal lands, including allowing for incorporation of new scientific information as it becomes available [21] [25]. It is noteworthy that some countries have elements in their legislature that ensure the use of sciences in environmental policies. For example, some state and federal policies for US public lands and natural resource management require the use of best available science information, or BASI [27]. The Nature Conservation Act in Iceland (60/2013) has such provisions, which are, however, not implemented in ration to grazing practices of degraded land in Iceland.

Challenges facing the field officers are often complex, as reported by Berglund et al. [28]. There is a need for better linkages between the research and science capacity of the SCSI and other agencies involved in the schemes, on one hand, and the people in the field on the other. High educational standards should be set for work of this kind and a concerted effort by the SCSI and the university system is needed to raise the knowledge level on which the work is based. It should be noted here that the IFVA has no specialists in this field.

\section{Conclusions}

The research presented here provides evidence of closed, non-transparent system, for handing out green subsides to Icelandic sheep farmers. It highlights the importance of relatively recently established legal instrument, The Information $A c t$, for accessing information about key environmental issues in Iceland. Land Improvement Plans (LIP's) under the Quality Management System (QMS) have only been made for parts of Icelandic rangelands, with no or limited information about why other areas do not need such plans. The concept "Sustainable land use" is at the core of the QMS and it is also widely used in the marketing of sheep products. The study shows multiple evidence that the implementation of the QMS does not recognize the underlying concepts of sustainable land management, including the five objectives discussed by Smyth and Dumanski [16]. The fact is that most of the land in question fails to meet criteria for adequate land condition now and in the foreseeable future. The LIP's utilize overly simplified information that is user-rather than ecologically based. Furthermore, most of the LIP areas are heavily grazed. It is therefore logical to ask if the QMS has been misused to justify "green-subsidies" to the sheep production sector in Iceland.

The study provides an example of how the knowledge and advice of a national agency responsible for dealing with land condition are repeatedly ignored. To avoid conflict at the governance level, environmental regulations for sheep grazing should be hosted by one agency under one governmental entity, namely the Ministry for the Environment and Natural Resources. The new law for soil conservation in Iceland (155/2018) did not address this dilemma and still refers portions of land use management to an out-of-date Act on Rangelands (no 6/1986, mostly set in 1969) under the Ministry of Industries and Innovation. This is likely to 
maintain status quo and hamper the implementation of good land use practices in Iceland.

The information presented herein strongly suggests a need to reconsider legislation in relation to green subsidies for sheep production in Iceland. Ideally, new law would entail transparent management and decision mechanism with multiple stakeholder participation, including NGO's, scientists, nature research agencies, communities and the general public, in addition to current land users. Such co-management approaches need to have a clear mandate to halt grazing in areas that do not support sustainable land use. Also, multi-sectoral approach would increase chances of finding alternative job opportunities for users negatively affected by a management decision. It is imperative that other means of subsidies be made available to farms and farmers where grazing is unsustainable and needs to be stopped-including employment in tourism, afforestation, and ecological restoration.

\section{Conflicts of Interest}

The author declares no conflicts of interest regarding the publication of this paper.

\section{Note on Legislation}

All law texts cited in the paper were retrieved in Icelandic from the Althingi (Parliament) webpage (https://www.Althingi.is). Some can be retrieved in English from the Government Offices of Iceland webpage, https://www.government.is/publications/legislation/. Both websites allow for entering the number/year of each law to download the full text of the law. The texts of government regulations were retrieved from https://www.reglugerd.is in Icelandic.

\section{References}

[1] Helgadottir, A., Eythorsdottir, E. and Johannesson, T. (2013) Agriculture in Iceland-A Grassland Based Production. Grassland Science in Europe, 18, 30-43.

[2] OECD (2019) Agricultural Support (Indicator).

[3] Arnalds, O. (2015) The Soils of Iceland. Chapter 12. Collapse, Erosion, Condition and Restoration. Springer, Dordrecht. https://doi.org/10.1007/978-94-017-9621-7_12

[4] Arnalds, O., Thorarinsdottir, E.F., Metusalemsson, S., Jonsson, A., Gretarsson, E. and Arnason, A. (1997) Jarðvegsrof á Íslandi (Soil Erosion in Iceland). Soil Conservation Service and Agricultural Research Institute, Reykjavik, 157 p. (In Icelandic)

[5] Arnalds, O. and Barkarson, B. (2003) Soil Erosion and Land Use Policy in Iceland in Relation to Sheep Grazing and Government Subsidies. Environmental Science and Policy, 6, 105-113. https://doi.org/10.1016/S1462-9011(02)00115-6

[6] Crofts, R. (2011) Healing the Land. Soil Conservation Service of Iceland, Gunnarsholt, Iceland.

[7] OECD (2014) Environmental Performance Review: Iceland 2014. OECD, Paris. 
[8] Petursdottir, Th., Aradottir, A.L., Baker, S., Halldorsson, G. and Sonneveld, B. (2017) Successes and Failures in Rangeland Restoration: An Icelandic Case Study. Land Degradation and Development, 28, 34-45. https://doi.org/10.1002/ldr.2579

[9] Aradottir, A.L., Petursdottir, Th., Halldorsson, G., Svavarsdottir, K. and Arnalds, O. (2013) Drivers of Restoration-Lessons from a Century of Restoration in Iceland: A Review. Ecology and Society, 18, 33. https://doi.org/10.5751/ES-05946-180433

[10] UU (2018) Information Ruling Committee Ruling 747. (In Icelandic) https://www.stjornarradid.is/gogn/urskurdir-og-alit-/stakur-urskurdur/2018/08/07/ 747-2018.-Urskurdur-fra-31.-juli-2018

[11] Fannarsson, B.S., Barkarson, B.H., Pétursson, J.G. and Helgadóttir, S.S. (2018) Reform of the Icelandic Soil Conservation Law. In: Ginzky, H., Dooley, E., Heuser, I.L., Kasimbazi, E., Markus, T. and Qin, T., Eds., International Yearbook of Soil Law and Policy 2017, Springer, Cham, 223-243.

https://doi.org/10.1007/978-3-319-68885-5_12

[12] Stefansson, J.H. (2018) Of Sheep and Man. Analysis of the Agri-Environmental Cross-Compliance Policies in the Icelandic Sheep Grazing Regime. MA Thesis, Faculty of Social Sciences, University of Iceland, Reykjavik.

[13] Arnalds, O., Thorsson, J. and Thorarinsdottir, E.F. (2003) Land Use and Ecofriendly Production of Sheep Products. Agricultural Research Institute Report 211, Agricultural University of Iceland, Hvanneyri. (In Icelandic)

[14] Gisladottir, F.O., Brink, S.H. and Arnalds, O. (2014) Nytjaland. Agricultural University of Iceland Report No. 49, Hvanneyri.

http://www.lbhi.is/sites/lbhi.is/files/gogn/vidhengi/rit_lbhi_nr_54.pdf

[15] Jonsdottir, S. (2010) Sheep Pastures, Guide for Assessing Condition of Grazing Lands ("Sauðfjárhagar, Leiðbeiningar við mat á ástandi beitilanda”). Soil Conservation Service of Iceland, Gunnarsholt. http://www.land.is

[16] Smyth, A.J. and Dumanski, J. (1993) FESLM. An International Framework for Evaluating the Sustainable Land Management. FAO World Resource Report 73. FAO, Rome.

[17] Lefroy, R.D.B., Bechstedt, H.-D. and Rais, M. (2000) Indicators for Sustainable Land Management Based on Farmer Surveys in Vietnam, Indonesia, and Thailand. Agriculture, Ecosystems and Environment, 81, 137-146. https://doi.org/10.1016/S0167-8809(00)00187-0

[18] Barrio, I.C., Hik, D.S., Thorsson, J., Svavarsdottir, K., Marteinsdottir, B. and Jónsdóttir, I.S. (2018) The Sheep in Wolf's Clothing? Recognizing Threats for Land Degradation in Iceland Using State-and-Transition Models. Land Degradation and Development, 29, 1714-1725. https://doi.org/10.1002/ldr.2978

[19] Halldorsson, G., Agustsdottir, A.M., Aradottir, A.L., Arnalds, O., Nilsson, C., Oskarsson, H., Mortensen, L., Pagneux, E., Pilli-Sihvola, K., Raulund-Rasmussen, K., Svavarsdottir, K. and Tolvanen, A. (2017) Ecosystem Restoration for Mitigation of Natural Disasters. TemaNord, 546. https://doi.org/10.6027/ANP2017-743

[20] Hurni, H. (2000) Assessing Sustainable Land Management (SML). Agriculture, Ecosystems \& Environment, 81, 83-92. https://doi.org/10.1016/S0167-8809(00)00182-1

[21] Caves, J.K., Bodner, G.S., Simms, K., Fisher, L.A. and Robertson, T. (2013) Integrating Collaboration, Adaptive Management, and Scenario-Planning: Experiences at Las Cienegas National Conservation Area. Ecology and Society, 18, 43. https://doi.org/10.5751/ES-05749-180343

[22] Thorlaksdottir, J.S. (2015) Connecting Sustainable Land Use and Quality Manage- 
ment in Sheep Farming: Effective Stakeholder Participation or Unwelcome Obligation? MSc Thesis, Faculty of Life and Environmental Sciences, University of Iceland, Reykjavik.

[23] Burton, R.J.F. and Paragahawewa, U.H. (2011) Creating Culturally Sustainable Agri-Environmental Schemes. Journal of Rural Studies, 27, 95-104. https://doi.org/10.1016/j.jrurstud.2010.11.001

[24] Sheridan, T.E., Nabhan, G.P. and Charnley, S. (2014) Conclusions and Policy Implications. In: Charnley, S., Sheridan, T.E. and Nabhan, G.P., Eds., Stitching the West Back Together, The University of Chicago Press, Chicago, 301-310. https://doi.org/10.7208/chicago/9780226165851.003.0025

[25] Sheridan, T.E., Sayre, N.F. and Sibert, D. (2014) Beyond "Stakeholders" and Zero-Sum Game: Towards Community-Based Collaborative Conservation in the American West. In: Charnley, S., Sheridan, T.E. and Nabhan, G.P., Eds., Stitching the West Back Together, The University of Chicago Press, Chicago, 53-75.

[26] Atari, D.O.A., Yiridoe, E.K., Smale, S. and Duinker, P.N. (2009) What Motivates Farmers to Participate in the Nova Scotia Environmental Farm Plan Program? Evidence and Environmental Policy Implications. Journal of Environmental Management, 90, 1269-1279. https://doi.org/10.1016/j.jenvman.2008.07.006

[27] Esch, B.E., Waltz, A.E.M., Wasserman, T.N. and Kalies, E.L. (2018) Using Best Available Science Information: Determining Best and Available. Journal of Forestry, 116, 473-480. https://doi.org/10.1093/jofore/fvy037

[28] Berglund, B., Hellgren, L. and Aradottir, A.L. (2015) Stakeholder Interaction in Participatory Land Restoration in Iceland: Environmental Officers' Challenges and Strategies. Environmental Management, 56, 519-531.

https://doi.org/10.1007/s00267-015-0506-0

\section{List of Abbreviations}

FAO: Food and Agricultural Organization of the United Nations

IFVA: Icelandic Food and Veterinary Authority

NGO: Non-Governmental Organizations

LIP: Land Use Implementation Plan, a part of the Quality Management System (QMS)

L-QMS: Land use part of the Quality Management System under which subsidy payments are made to farmers if land use criteria are met.

OECD: Organization for Economic Cooperation and Development

QMS: An Icelandic sheep subsidy payment system linked to criteria for ensuring quality of the product, the farm environment and of the grazing areas, with guidelines for maximum grazing intensities, the criteria need to be met in order to be entitled to receive the full amount of subsides.

SCSI: Soil Conservation Service of Iceland. 